\title{
Synthesis and Spectroscopic Investigation of Novel Nickel(II) Complexes from Pentadentate Schiff Base Ligand
}

\author{
Rangaswamy Venkatesh and Kannappan Geetha* \\ PG\& Research Department of chemistry, Muthurangam Govt. Arts College(Autonomous), Vellore-2
}

Received: May 25, 2015; Accepted: June 14, 2015; Published: July 01, 2015

*Corresponding author: Dr. K Geetha, PG\& Research Department of chemistry, Muthurangam Govt. Arts College (Autonomous), Vellore-2, Tel: +91 09486925596; +910416 2262068; Fax: +910416 2263768; E-mail: senthil_geetha@rediffmail.com

\begin{abstract}
The coordination chemistry of dinucleating ligands is currently an area of great activity. One reason for this is the facile synthesis of dinuclear species toward model compounds of metallo-enzymes. On the other hand, these multidentate ligands might be useful as building blocks for high-nuclearity compounds. Three different para substituted dinuclear nickel(II) complexes $\left[\mathrm{Ni}_{2} \mathrm{~L}\left(\mathrm{O}_{2} \mathrm{CC}_{6} \mathrm{H}_{4}-\mathrm{p}-\mathrm{X}\right)\right]$ ] $\left.\mathrm{X}=\mathrm{NO}_{2}(1), \mathrm{Cl}(2), \mathrm{OCH}_{3}(3)\right]$ were synthesized by the reaction of corresponding precursor with pentadentate Schiff base ligand. The ligand was characterized by UV-Visible, FTIR, NMR studies. The synthesized complexes were characterized by molar conductance, UV- Visible, FTIR, LCMS spectral studies.
\end{abstract}

Keywords: Penta-Dentate Schiff Base Ligand; Nickel(II) Precursors; Novel Nickel(II) Complexes

\section{Introduction}

Over the past two decades, extensive research has been carried out on symmetrical bis-Schiff base ligands and their transition metal complexes, which can be prepared by usual condensation of one mole of diamine and two moles of $\beta$-diketone or an aromatic 0-hydroxy carbonyl compound [1-5]. But there are only a few reports regarding with synthesis of unsymmetrical Schiff bases derived from equimolar condensation of a diamine and different aldehydes / ketones which is more difficult to obtain. During the recent years, there has been a remarkable interest in the design, synthesis and characterization of transition metal complexes of unsymmetrical Schiff base ligands from the fact that the central metal ions in natural systems are in unsymmetrical organic moieties [6-12]. Hence transition metal complexes synthesized from unsymmetrical Schiff bases serve as models of relevance to bio-inorganic chemistry such as metallo proteins and metallo enzymes in which transition metal ions are found usually in a disorted environment. Unsymmetrical Schiff base complexes have shown wide spectrum of applications such as biochemical, analytical, and antimicrobial agents $[13,14]$.

Sau-Fun et al reported unsymmetrical bis-Schiff base ligands by partial displacement of the symmetrical bis-Schiff bases of ethylenediamine and salicylaldehyde/ 0-hydroxyacetophenone/ acetylacetone/ benzoylacetone which have led to the formation and isolation of unsymmetrical Schiff base ligands. Nickel(II) and copper(II) complexes of these ligands have been prepared and characterized $[15,16]$

This paper reports on the synthesis and characterization of Nickel (II) complexes using pentadentate Schiff base ligand obtained from 5-nitro salicylaldehyde with salicylaldehyde and 1,3-diamino-2-propanol.

\section{Experimental Materials and methods}

1,3-diamino-2-propanol was purchased from Alfa Aesar, all other chemicals and solvents were purchased from commercial sources and were used after purification. Conductance of complexes was recorded using Elico conductometer. UV-Vis spectra were recorded using Systronics spectrophotometer operating in the range of $200-800 \mathrm{~nm}$ with quartz cell. FT-IR spectra of ligand and complexes were obtained on a Schimadzu IR-Affinity-I spectrometer and samples were prepared using $\mathrm{KBr} .{ }^{1} \mathrm{H}$ NMR spectrum of Schiff base ligand was recorded using Bruker $400 \mathrm{MHz}$ model.

\section{Synthesis of ligand}

The ligand was synthesized by using 1, 3-diamino-2propanol $(10 \mathrm{mmol})$ with 5 -nitro salicylaldehyde $(10 \mathrm{mmol})$ and salicylaldehyde (10 mmol) in the ratio of 1:1:1 using ethanol as a solvent and the mixture was refluxed for 6 hours. Colour change was observed and the reaction was monitored by TLC primarily using hexane as eluent. It was characterized by UV-Vis, FT-IR and ${ }^{1}$ HNMR spectral studies.

\section{Synthesis of Nickel (II) Precursors}

The Nickel(II) precursors were synthesized by using organic acids para-nitro benzoic acid, para-chloro benzoic acid and paramethoxy benzoic acid( $10 \mathrm{mmol}$ ) with $\mathrm{NaOH}(20 \mathrm{mmol})$ were stirred for 10 minutes and $\mathrm{NiSO}_{4} \cdot 6 \mathrm{H}_{2} \mathrm{O}(20 \mathrm{mmol})$ was added to above mixture and magnetically stirred with 30 minutes. The ratio of organic acid, base and metal was taken as 1:2:2 for the 
synthesis of Nickel (II) Precursors. The crude green Nickel (II) precursors obtained was washed thoroughly with water and dried well. The Nickel (II) precursors obtained was used for the synthesis of Nickel (II) complexes.

\section{Synthesis of Nickel (II) complexes}

A general method was used for the preparation of Dinuclear Nickel(II) complexes. The ligand $(2 \mathrm{mmol})$ with $\mathrm{KOH}(6 \mathrm{mmol})$ and Nickel(II) precursor( $2 \mathrm{mmol}$ ) was refluxed for 6 hours using ethanol as a solvent. The ratio of the ligand, $\mathrm{KOH}$, Nickel (II) precursors were taken as 1:3:1 for the synthesis of Dinuclear Nickel(II) complexes. The complexes formed were characterized by UV-Vis, FT-IR, Conductivity measurement and LCMS. The scheme for the preparation of the ligand and complexes are given below. The scheme of the ligand and its complex are shown in Figure 1 and Figure 2.

\section{Results and Discussion}

\section{Conductance Measurements}

Molar Conductivity measurements values revealed nonelectrolytic nature of Nickel (II) complexes [17], since for the molar conductance values are in the range for non-electrolytes. The solvent used for conductance measurement is DMF. The physical properties and conductance of the metal complexes values are listed in Table.1.

\section{UV-Visible Spectra}

The UV-Visible spectra of the ligand was recorded in DMF in the wavelength range $200-800 \mathrm{~nm}$. The complexes were recorded in the DMF solution in the above wave length range. The band observed at $245 \mathrm{~nm}$ was due $\pi-\pi^{*}$ transition of the benzene ring present in the ligand and it shifted to higher wavelength(red shift) upon complexation and the band was observed at 255, 250 and $270 \mathrm{~nm}$ respectively for complex-I,II \&III. The band at 355

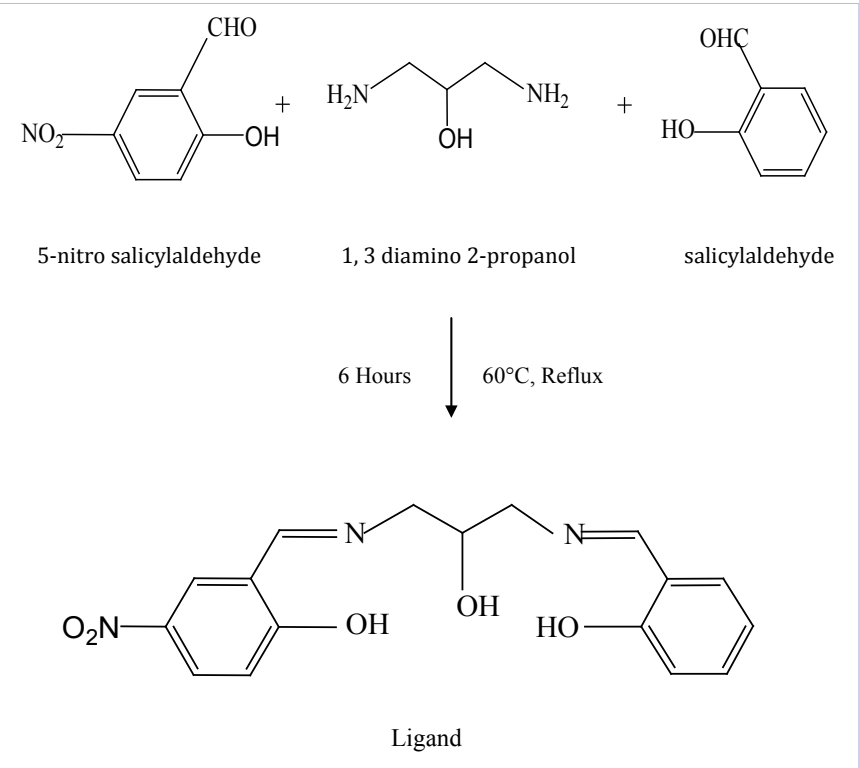

Figure 1: The scheme of the Ligand.

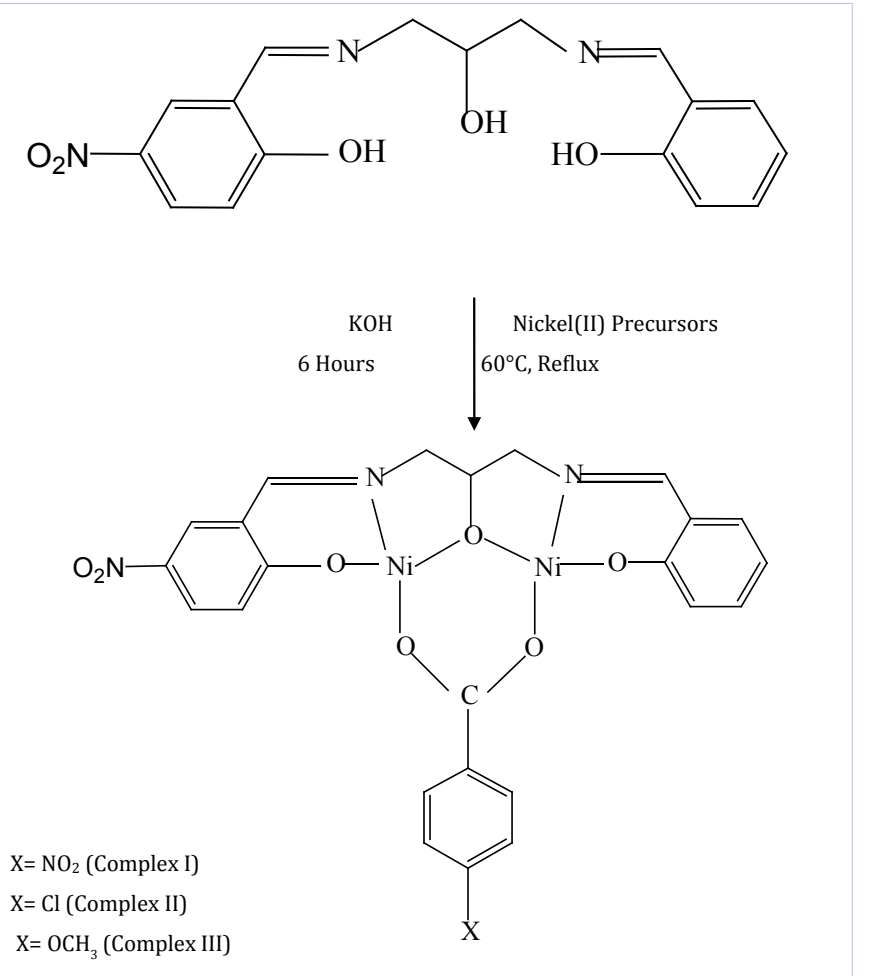

Figure 2: The scheme of the complex.

\begin{tabular}{|l|l|l|c|}
\hline \multicolumn{2}{|c|}{ Table-1: Physical properties and Conductance of the metal complexes. } \\
\hline Compound & Molecular formula & Colour & $\begin{array}{l}\text { Molar } \\
\text { Conductance (S } \\
\text { cm }^{2} \text { mol }^{-1} \text { ) }\end{array}$ \\
\hline Complex-I & $\mathrm{C}_{24} \mathrm{H}_{18} \mathrm{~N}_{4} \mathrm{O}_{9} \mathrm{Ni}_{2}$ & Light Green & 4.0 \\
\hline Complex-II & $\mathrm{C}_{24} \mathrm{H}_{18} \mathrm{~N}_{3} \mathrm{O}_{7} \mathrm{ClNi}_{2}$ & Light Green & 12.9 \\
\hline Complex-III & $\mathrm{C}_{25} \mathrm{H}_{21} \mathrm{~N}_{3} \mathrm{O}_{8} \mathrm{Ni}_{2}$ & Light Green & 4.9 \\
\hline
\end{tabular}

Table 2: IR data for ligand and its complexes.

\begin{tabular}{|c|c|c|c|c|}
\hline $\begin{array}{l}\text { Functional } \\
\text { group }\end{array}$ & $\begin{array}{l}\text { Ligand } \\
\left(\mathrm{cm}^{-1}\right)\end{array}$ & $\begin{array}{l}\text { Complex-I } \\
\left(\mathrm{cm}^{-1}\right)\end{array}$ & $\begin{array}{l}\text { Complex-II } \\
\left(\mathrm{cm}^{-1}\right)\end{array}$ & $\begin{array}{l}\text { Complex- } \\
\text { III }\left(\mathbf{c m}^{-1}\right)\end{array}$ \\
\hline $\mathrm{v}(\mathrm{C}=\mathrm{N})$ & 1635 & 1618 & 1620 & 1616 \\
\hline $\begin{array}{c}v(\mathrm{C}-\mathrm{O}) \\
\text { (Phenolic) }\end{array}$ & 1307 & 1313 & 1308 & 1315 \\
\hline $\mathrm{v}(-\mathrm{OH})$ & 3142 & - & - & - \\
\hline $\mathrm{u}(\mathrm{Ni}-\mathrm{N})$ & - & 524 & 545 & 530 \\
\hline $\mathrm{v}(\mathrm{Ni}-\mathrm{O})$ & - & 466 & 474 & 466 \\
\hline $\mathrm{v}(\mathrm{Ni}-\mathrm{OCO})$ & - & 1579,1475 & 1579,1471 & 1583,1487 \\
\hline
\end{tabular}

$n m$ was due to $\pi-\pi^{*}$ transition of the azomethine group present in the ligand and it shifted to higher wave length observed at 390,370 and $380 \mathrm{~nm}$. This shows the coordination of metal with the azomethine nitrogen [18]. The weak band observed at 470 , 480 and $460 \mathrm{~nm}$ was due to $\mathrm{n}-\pi^{*}$ transition of complex-I, II \&III. The new characteristic band at $640,642,641 \mathrm{~nm}$ was due to d-d transition of complex-I, II\& III. UV-Visible spectrum for ligand and its complexes shown in Figure 3. 

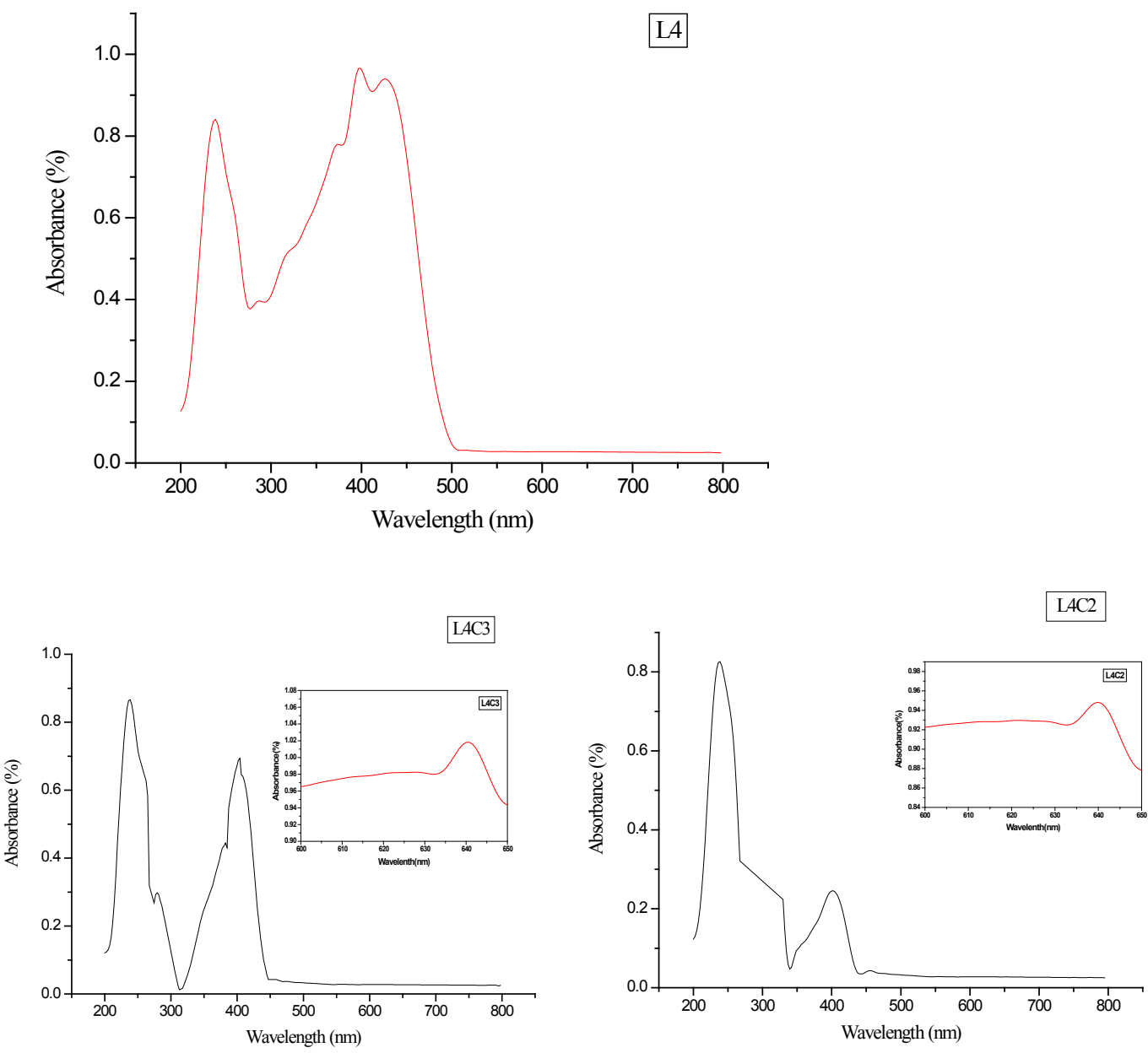

Complex-III

complex-I

Figure 3: UV-Visible spectrum for ligand and its complexes shown.

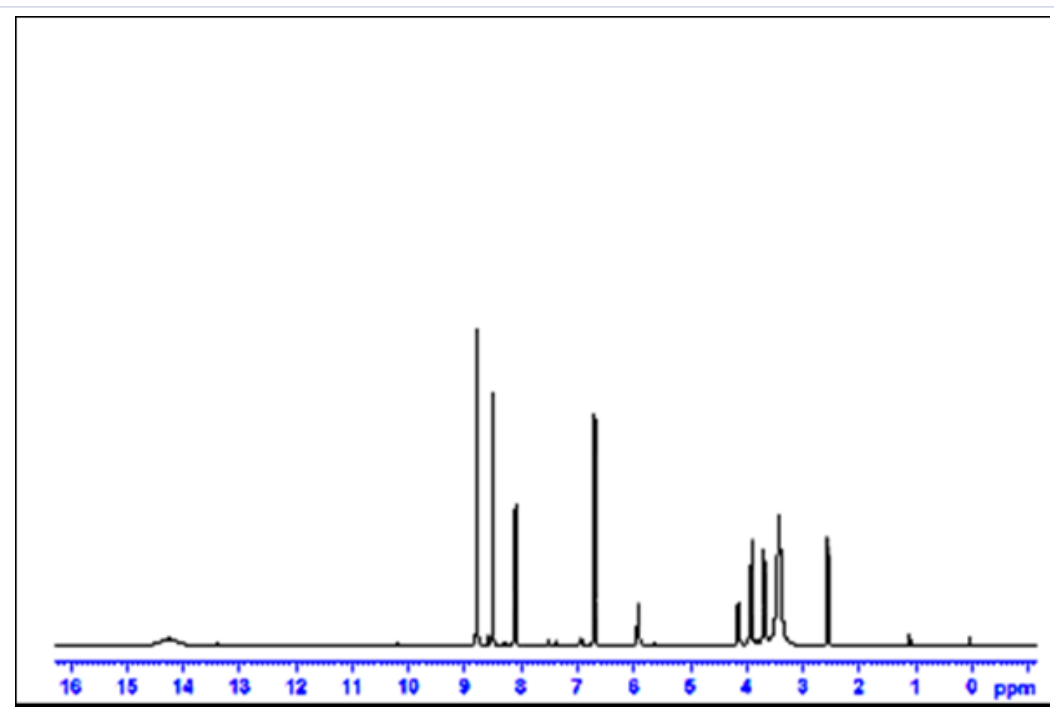

Figure 4: The NMR spectrum of ligand. 


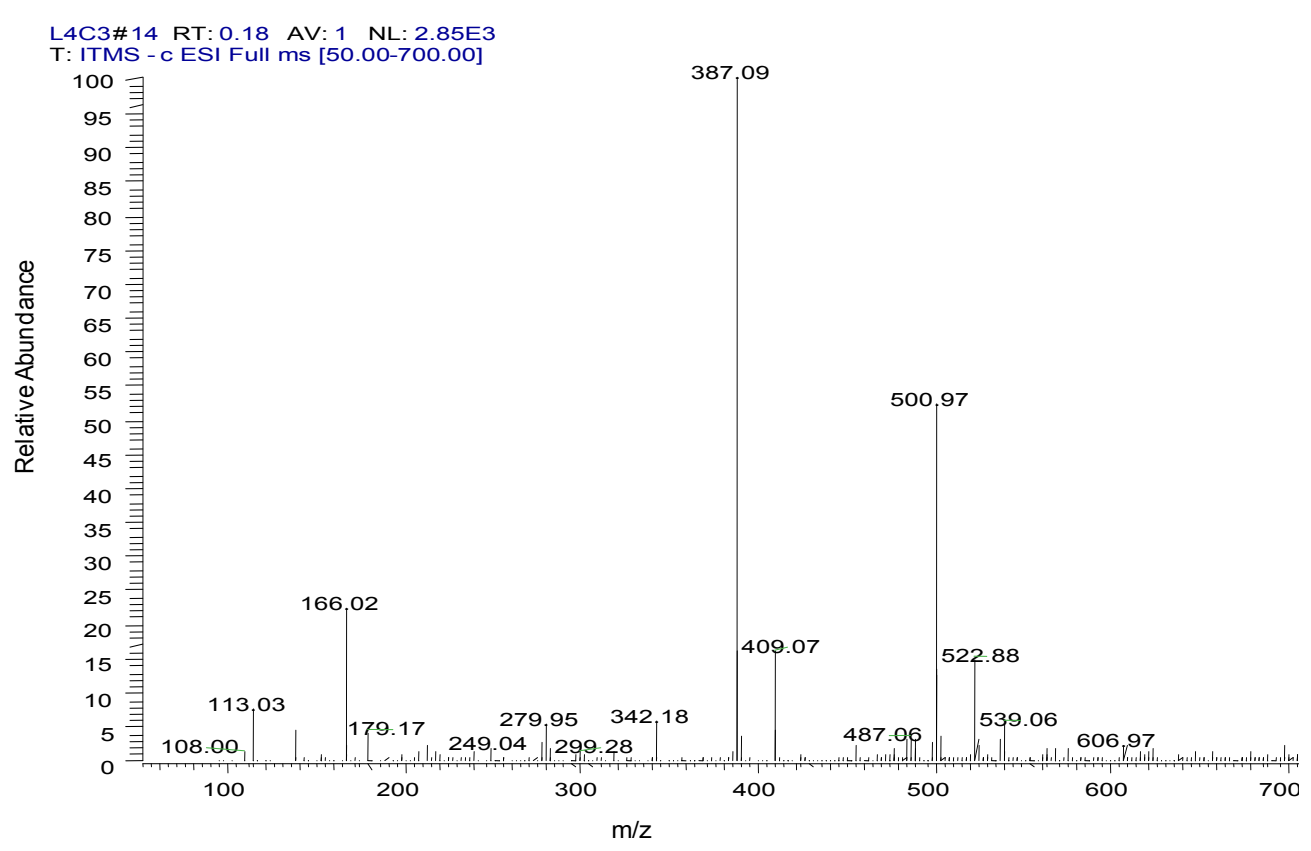

Figure 5: The mass spectrum of complex (III).

\section{Infrared Spectra}

In order to study the binding mode of ligand to metal in the complexes, IR spectrum of the free Schiff base ligand was compared with the spectra of the metal complexes. The free ligand exhibits IR peaks at $3142 \mathrm{~cm}^{-1}(\mathrm{O}-\mathrm{H}), 1635 \mathrm{~cm}^{-1}(\mathrm{C}=\mathrm{N})$ and $1307 \mathrm{~cm}^{-1}$ phenolic (C-0) $[19,20]$. In complexes the peak due to $(\mathrm{O}-\mathrm{H})$ of the ligand disappeared indicating the co-ordination of phenolic oxygen to the metal ion via deprotonation. This was further supported by upward shift to the phenolic (C-O) mode. The peak at $1635 \mathrm{~cm}^{-1}$ was due to azomethine group of the ligand and it shifted to lower frequency after complexation. This shows the co-ordination of metal with azomethine nitrogen [21]. Some new bands have also appeared indicating the complexation of metal with the ligand corresponds to $(\mathrm{Ni}-\mathrm{N}),(\mathrm{Ni}-\mathrm{O})$ and $(\mathrm{Ni}-$ OCO). IR data for ligand and its complexes are shown in Table. 2

\section{${ }^{1} \mathrm{H}-\mathrm{NMR}$ of the Ligand}

The ligand was characterized by ${ }^{1} \mathrm{H}-\mathrm{NMR}$ and the values were obtained at $2.5 \delta$ for secondary alcohol proton; $3.4 \delta$ for methylene proton; $6.69 \delta$ for azomethine group; $8.78 \delta$ for phenolic proton. The solvent used for NMR spectrum is DMSO- $\mathrm{d}^{6}$. NMR data for ligand shown in Figure 4

\section{Mass spectrum of the Complex}

The mass spectrum of complex (III) exhibited peak at $\mathrm{m} / \mathrm{z}$ 606.97, this is in good agreement with the proposed molecular formula of molecular weight 607. The peak at 166 is due to $\mathrm{C}_{7} \mathrm{H}_{4} \mathrm{NO}_{4}$, the peak at 387 is due to $\mathrm{C}_{11} \mathrm{H}_{12} \mathrm{~N}_{2} \mathrm{O}_{6} \mathrm{Ni}_{2}$ and the peak at 487 is due to $\mathrm{C}_{17} \mathrm{H}_{14} \mathrm{~N}_{3} \mathrm{O}_{7} \mathrm{Ni}_{2}$. The mass spectrum of complex (III) shown in Figure 5.

\section{Conclusion}

In the present work three dinuclear nickel (II) complexes were synthesized and characterized by various analytical techniques like molar conductance, electronic, vibrational, NMR and LCMS studies. IR spectral data showed that the ligand acts as pentadentate coordinating through azomethine nitrogen and oxygen atoms. The lower molar conductance values suggested the non-electrolytic nature of the complexes.

\section{References}

1. Ueno K \& Martell AE. J Phys Chem. 1995;59:998.

2. Mc Carthy PJ, Hovey RJ, Ueno $\mathrm{K}$ and Martell AE. Inner Complex Chelates. I. Analogs of Bisacetylacetoneethylenediimine and its Metal Chelates $^{1,2}$. J Am Chem Soc. 1955;77(22):5820.

3. Bailes RH, Calvin M. The oxygen-carrying synthetic chelate compound. VII. Preparation ${ }^{1}$. J Am Chem Soc. 1947;69(8):1886-1893. DOI: $10.1021 / \mathrm{ja0} 1200 \mathrm{a} 013$

4. Carter MJ, Rillema DP, and Basolo F. Catalytic Activation of Dioxygen by Metal Complexes. J Am Chem Soc. 1974;96:392.

5. Tan SF, Ang KP, Jatchandran HL. Synthesis and Characterisation of copper (II), Ni(II) and palladium(II) complexes of some Schiff bases of dehydro acetic acid. Trans Met Chem. 1984;9(10):390-395.

6. Pandey YS and Mathur P. Polyhedron. 1994:13:3111.

7. Kwiatkowski M, Bandoli G. J Chem Soc. Dalton Trans. 1992;379.

8. Costes JP, Fernandez Garcia ML. Easy synthesis of half-units: their use as ligands or as precursors of non-symmetrical base complexes. Inorganica Chimica Acta. 1995;237(1):57-63. doi:10.1016/00201693(95)04641-L.

9. Jebbar-sid SD, Banali-Baitich O, Deloume JD. Polyhedran. 1997; $16: 2175$. 
10. Atkins R, Brewer G, Kokot E, Mockler GM, Sinn E. Copper(II) and nickel(II) complexes of unsymmetrical tetradentate Schiff base ligands, Inorg. Chem. 1985;24(2):127-134. DOI: 10.1021/ic00196a003

11. Kwiatkowski E, Kwiatowski M, Inorg. Chim. Acta. 1986;117:145.

12. Kwiatkowski M and Kwiatkowski E. J Chem Soc. Dalton Trans. 1985; 803-806. DOI: 10.1039/DT9850000803

13. Nora H, Al-Sha'alan H. Antimicrobial activity and spectral, Magnetic and thermal studies of some transition metal complexes of a Schiff base hydrazone containing a quinoline moiety. Molecules. 2007;12(5):1080-1091.

14. Nishant N, Parveen S, Dhyani S and Asma. Antimicrobial polyesters containing Schiff-base metal complexes. J Coord Chem. 2009;62(7):1091-1099.

15. Tan SF and Ang KP. Trans Met Chem. 1998;13:64-68.

16. Ray MS, Bhattacharya R, Chaudhuri S, Right L, Bocelli G, Mukhopadhyay G, Ghosh A. Synthesis, characterisation and X-ray crystal structure of copper(II) complexes with unsymmetrical tetradentate Schiff base ligands: first evidence of $\mathrm{Cu}(\mathrm{II})$ catalysed rearrangement of unsymmetrical to symmetrical complex. Polyhedron. 2003;22(4):617624. doi:10.1016/S0277-5387(02)01435-3.
17. Geary WJ. The use of conductivity measurements in organic solvents for the characterization of coordination compounds. Coord chem Rev. 1971;7(1):81-122.

18. Nevin Turan and Memet Sekerci. Synthesis and characterization of $\mathrm{Co}(\mathrm{II}), \mathrm{Ni}(\mathrm{II}), \mathrm{Cd}(\mathrm{II})$ and $\mathrm{Cu}(\mathrm{II})$ complexes of Bis-schiff bases obtained from 1,8- Diamino naphthalene. J Chem Soc Pak. 2009;31(4):564568.

19. Manikshete AH, Awatade MM, Sarsamkar SK, Asabe MR. Synthesis, characterization, antimicrobial, anticancer and antidiabetic activity of new Manganeae (II), Nickel (II) and Cobalt (II) complexes with Salicylaldehyde-4-chlorobenzoylhydrazone. International Journal of Engineering Science Invention. 2015;4(1):22-29.

20. Mohanan K, Subhadrambika N, Selwin Joseyphus R, Swathy SS, Nisha VP. Synthesis, spectroscopic characterization, solid state d.c electrical conductivity and biological studies of some lanthanide(III) chloride complexes with a heterocyclic Schiff base ligand. Jounal of Saudi chemical Society. 2012. doi:10.1016/j.jscs.2012.07.007

21. Marius Andruh, Olivier Kahn, Joelle Sainton, Yves Dromzee, Suzanne Jeannin. Oxophily of gadolinium(III) and synthesis of dissymmetric di(Schiff bases) and Dissymmetric dinuclear compounds-crystalstructure of [Cu2L'(OH)] (CLO4)2.H20 with L'=-6-[N-Dimethyl Amino) Propyl)Formimidoyl] Phenolato" Inorg. Chem. 1993;32(9):16231628. DOI: $10.1021 /$ ic00061a018. 